\title{
ACCUMULATION FEATURES OF MICRO AND MACROELEMENTS IN INDIGENOUS AND ALIEN MOLLUSCS IN SALDANHA BAY, SOUTH AFRICA
}

\begin{abstract}
Alien Mediterranean mussels Mytilus galloprovincialis, Pacific oysters Crassostrea gigas and indigenous Cape mussels Choromytilus meridionalis were used as sentinel biomonitors of inorganic pollutants in Saldanha Bay, South Africa. Neutron activation analysis was used to determine the concentrations of 33 macro and microelements in the soft tissues of molluscs. The Mediterranean mussels significantly demonstrated the higher accumulation ability to $\mathrm{S}, \mathrm{Se}$ and $\mathrm{Br}$ than the Pacific oysters, whereas the Pacific oysters - to $\mathrm{Fe}, \mathrm{Cu}, \mathrm{Zn}$ and As. The Cape mussels are more sensitive to $\mathrm{Mn}$ and As and the Mediterranean mussels were sensitive to $\mathrm{Zn}$ and $\mathrm{Se}$.
\end{abstract}

Keywords: elemental accumulation, Indigenous and alien molluscs, trace elements, Neutron Activation Analysis, Mytilus galloprovincialis, Crassostrea gigas, Choromytilus meridionalis

\section{Introduction}

Environmental monitoring activities are essential to assess the contamination of terrestrial and aquatic ecosystems. Many studies proposed to use bivalve molluscs as sentinel organisms for monitoring levels of environmental pollutants in water [1-3]. Since the study of Goldberg [4], "Mussel Watch" projects had successfully been used in several countries around the world, which includes the coastline around the Cape Peninsula in South Africa [5]. These bivalve biomonitors include mussels and oysters, which filter large amounts of water and accumulate nutrients and pollutants from the environment. Its ability was studied in different geographical conditions [6] and can be used as a basic feature of molluscs in future biomonitoring studies.

In the study, we were used Saldanha Bay as a research area. It is situated on the West Coast of South Africa and includes a deep-water harbour that is connected to the Langebaan Lagoon (West Coast National Park), which is a marine protected area. The larger area around the bay contains industrial activities such as seafood processing plants, steel industries and multifunctional loading jetties. A new Industrial Development

\footnotetext{
${ }^{1}$ Faculty of Military Science, Stellenbosch University, Victoria Street, Stellenbosch, South Africa, phone +27218089111, fax +27218083822

${ }^{2}$ FLNP Sector NAA \& Applied Research, Division of Nuclear Physics, Frank Laboratory of Neutron Physics, Joint Institute for Nuclear Research, Dubna, 141980, Russia

${ }^{3}$ Horia Hulubei National Institute for R\&D in Physics and Nuclear Engineering, 30 Reactorului Str. MG-6, Bucharest - Magurele, Romania

*Corresponding author: p.nekhoroshkov@gmail.com
} 
Zone (IDZ) was recently founded in the Saldanha Bay Area notwithstanding the exceptional ecological importance of the bay [7]. The IDZ is therefore developed under constant monitoring of the impact of the anthropogenic activities on the environment. Such accompanied control includes the study of molluscs as natural biomonitors [8]. The bottom of the bay, beneath the rafts with farmed molluscs, mainly comprises silt-like sediments that are remobilized when the weather conditions deteriorate. This causes emissions from the loading pier to be desorbed from sediments to the overlying water. The molluscs then filter and naturally accumulate the elements at a concentration that corresponds to natural concentrations of these elements in polluted and pristine areas [9]. It is an important part of biomonitoring to determine the accumulation ability of molluscs in the remobilized sediments condition.

The Mediterranean mussels (Mytilus galloprovincialis (Lamarck, 1819) - MG) that are found in and around Saldanha Bay are the most abundant of all the bivalve molluscs in the area and were consequently chosen in our study as preliminary biomonitors [10]. During several decades, these invasive Mediterranean mussels are even more abundant than the indigenous Cape black mussels (Choromytilus meridionalis (Krauss, 1848) - CM) [11]. The Mediterranean and Cape mussels grow naturally on almost all the rocks in this part of the South African coastline but are also farmed on rafts and long lines in the inner part of Saldanha Bay. However, Pacific oysters (Crassostrea gigas (Thunberg, 1793) - CG) which do not grow naturally in the area are also farmed on the rafts alongside the mussels.

Elements such as $\mathrm{Cd}, \mathrm{Hg}, \mathrm{Pb}$ have been thoroughly studied by biomonitoring during old previous studies in the Saldanha Bay (for example the newest - [12]). Our study was focused on the analysis of around 40 elements in order to address the lack of knowledge with regard to these elements in molluscs. The aim of this study is therefore to investigate elements accumulation in indigenous and alien molluscs in Saldanha Bay.

Our previous studies determined the ranges of elemental concentrations in Mediterranean mussels at different sites in and around Saldanha Bay [13, 14]. In the current work, samples of indigenous mussels (CM), alien mussels (MG) and alien oysters (CG) at three key sites in the Saldanha Bay were chosen to be sampled in order to demonstrate the interspecies differences between them and their ability to be used as biomonitors of macro and microelements in the coastal zones.

\section{Material and methods}

\section{Sampling}

All the sampling sites were located in Saldanha Bay and near the harbour pier where various materials are loaded (Fig. 1). The different parts of Saldanha Bay and Langebaan Lagoon function as an integrated hydrological system. The sampling sites were chosen in two major water bodies of Saldanha Bay, namely: Small Bay and Big Bay (Fig. 1, Table 1). According to previous studies [7, 13, 14] the metal concentrations in molluscs and surrounded waters were the highest in Small Bay. The concentrations were lower in Big Bay and below the detection limits in Langebaan Lagoon.

Small Bay is hydrologically relatively uniform and the most isolated part of the Saldanha Bay and Langebaan Lagoon system. During April and August 2016, two sample sets of 10 mussels each (Mytilus galloprovincialis) were collected in Small Bay (site 1 in Fig. 1). These two sets were used for the analysis of temporary changes between two months (before and after the spawning period) in the accumulation of studied elements. 
During April 2016, an additional sample set of 10 mussels (Choromytilus meridionalis) were also sampled. The comparison between the two different mussel species, Choromytilus meridionalis (CM) and Mytilus galloprovincialis (MG) was done on the 20 samples, including 10 of each species (detailed in Table 6).

The oysters were only sampled in August 2016, but at two different sites: one in Small Bay (site 2 in Fig. 1) and one in Big Bay (site 3 in Fig. 1). The comparison between the mussel species (Choromytilus meridionalis and Mytilus galloprovincialis) and the oyster species (Crassostrea gigas) was done on samples from site 1, 2 and 3, respectively.

Table 1

Details of sampling

\begin{tabular}{|c|c|c|c|}
\hline Sampling sites & $\begin{array}{c}\text { Month } \\
\text { of 2016 }\end{array}$ & $\begin{array}{c}\text { Number of } \\
\text { samples }\end{array}$ & Species \\
\hline $\begin{array}{c}1-\text { Small Bay } \\
33.00458 \mathrm{~S} \\
17.96746 \mathrm{E}\end{array}$ & April & 10 & Choromytilus meridionalis \\
\cline { 2 - 4 } & April & 10 & Mytilus galloprovincialis \\
\hline $\begin{array}{c}1-\text { Small Bay } \\
33.00458 \mathrm{~S} \\
17.96746 \mathrm{E}\end{array}$ & August & 10 & Mytilus galloprovincialis \\
\hline $\begin{array}{c}2-\text { Small Bay } \\
33.0053 \mathrm{~S}\end{array}$ & August & 10 & Crassostrea gigas \\
\hline $\begin{array}{c}17.96437 \mathrm{E} \\
\text { 3- Big Bay } \\
33.03135 \mathrm{~S}\end{array}$ & August & 10 & Crassostrea gigas \\
\hline $18.00608 \mathrm{E}$ & & & \\
\hline
\end{tabular}

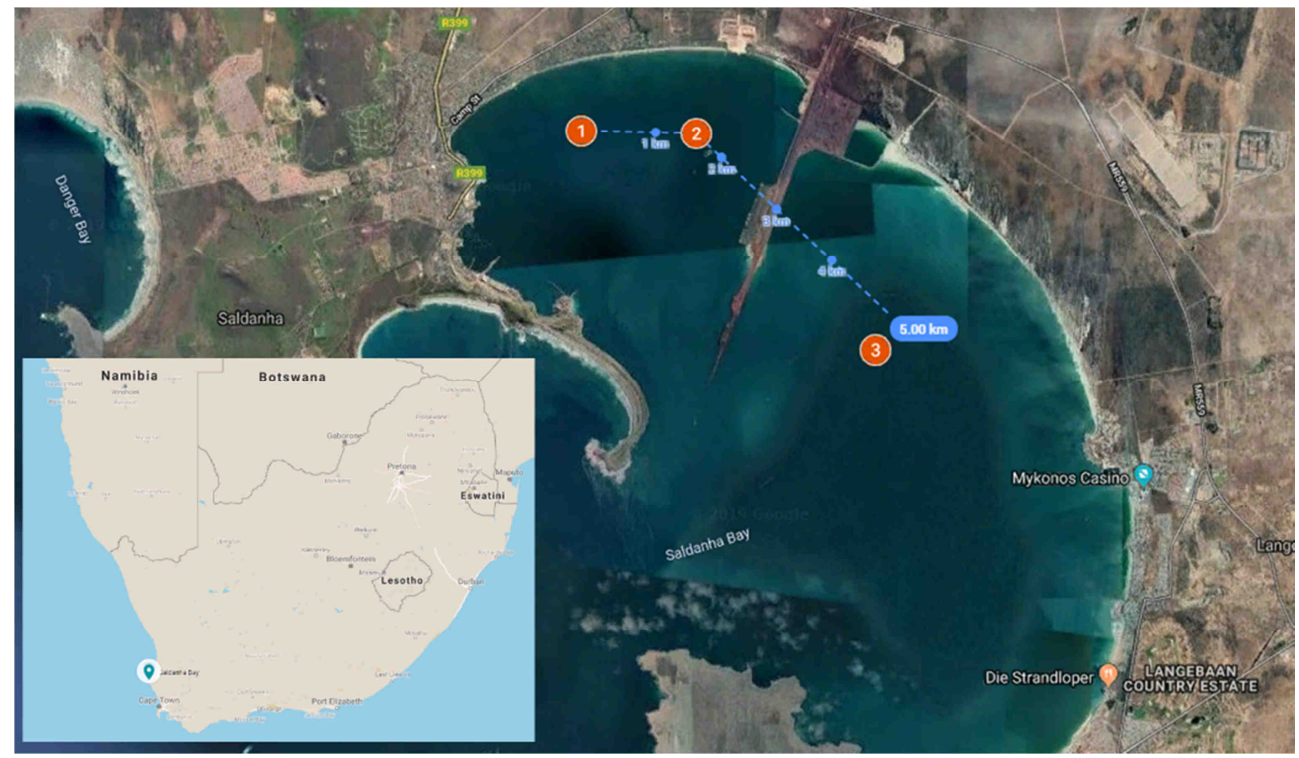

Fig. 1. Schematic view of Saldanha Bay that indicates sampling sites

All the samples were collected from rafts on mariculture farms. The rafts with the molluscs float at a depth ranging between $9 \mathrm{~m}$ and $13 \mathrm{~m}$, depending on the tidal cycles. 
After harvesting, the live samples were frozen and sent to the NAA analysis procedure. Then before analysis molluscs were defrosted and washed in freshwater and then underwent preliminary manual cleaning (by using a non-metallic knife) to delete the attached organisms. The lengths and weights of all the sampled molluscs were measured separately and are given in resulted Table 4 . The ages and sizes of each set of species due to selection varied insignificantly.

The soft tissues of the samples were finally extracted and packed in plastic bags, frozen and shipped to Dubna, Russia. The Neutron Activation Analysis (NAA) of the molluscs was conducted at the IBR-2 reactor of the Frank Laboratory of Nuclear Physics in the Joint Institute of Nuclear Research (Dubna, Russia) during the year of sampling.

\section{Neutron Activation Analysis}

The soft tissues were dried at a temperature of $40{ }^{\circ} \mathrm{C}$ to a constant weight and homogenised with a non-metallic mortar and pestle. The parameters of irradiation and determination of concentrations by the NAA are given in Tables 2 and 3. The detailed techniques are described in $[15,16]$, and applied to the South African molluscs earlier in $[13,14]$. For determination of short-lived isotopes of 8 elements $(\mathrm{Mg}, \mathrm{Al}, \mathrm{S}, \mathrm{Ca}, \mathrm{V}, \mathrm{Mn}, \mathrm{Cu}$ and I) approximately $0.3 \mathrm{~g}$ of material from each mollusc was packed in polyethylene bags, and irradiated for 3 minutes in the irradiation channel.

Neutron conditions of irradiation of the samples

\begin{tabular}{|c|c|c|c|c|c|c|}
\hline \multirow{2}{*}{ Channels } & \multicolumn{2}{|c|}{$\begin{array}{c}\text { Ch1 } \\
\text { (epithermal) } \\
\text { (cadmium-screened) }\end{array}$} & \multicolumn{3}{c|}{$\begin{array}{c}\text { Ch2 } \\
\text { (thermal) }\end{array}$} \\
\hline Dimensions [mm] & \multicolumn{2}{|c|}{ Diameter 28, length 260 } & \multicolumn{2}{|c|}{ Diameter 28, length 260 } \\
\hline Neutron type & Thermal & Resonance & Fast & Thermal & Resonance & Fast \\
\hline $\begin{array}{c}\text { Experimental } \\
\text { fluxes }\left[\mathrm{n} \cdot \mathrm{s}^{-1} \cdot \mathrm{cm}^{-2}\right]\end{array}$ & Cd-coated & $3.6 \cdot 10^{11}$ & $5.5 \cdot 10^{11}$ & $1.5 \cdot 10^{12}$ & $1.8 \cdot 10^{11}$ & $2.7 \cdot 10^{11}$ \\
\hline
\end{tabular}

The Gamma spectra of induced activity were measured for 15 minutes by using HPGe (high purity Germanium) detectors after 2 minutes of decay. To determine the long-lived isotopes of 21 elements ( $\mathrm{Na}, \mathrm{K}, \mathrm{Sc}, \mathrm{Cr}, \mathrm{Fe}, \mathrm{Co}, \mathrm{Ni}, \mathrm{Zn}, \mathrm{Se}, \mathrm{As}, \mathrm{Br}, \mathrm{Sr}, \mathrm{Rb}, \mathrm{Mo}, \mathrm{In}, \mathrm{Sb}, \mathrm{Cs}$, $\mathrm{Ba}, \mathrm{Au}, \mathrm{Th}, \mathrm{U})$, the samples were packed in aluminium cups and irradiated for 3 days in the cadmium screened irradiation channel. For these elements, the gamma-ray spectra were measured after 3 and 22 days to divide the different isotopes of elements according to techniques. The spectra of induced gamma activity were measured with HP Ge detectors with the resolution of $1.9 \mathrm{keV}$ for the ${ }^{60} \mathrm{Co} 1332 \mathrm{keV}$. The detected isotopes are shown in Table 2. Such rare earth and other microelements as La, Ce, Nd, Sm, Eu, Tb, Tm, Yb, Hf, $\mathrm{Ta}$ and $\mathrm{W}$ were determined by the NAA but were excluded from further analysis.

Quality control (Table 3) was provided by using different The Standard Reference Materials of National Institute of Standards and Technology (NIST SRMs): 1547, 1633b, $1633 \mathrm{c}, 2709,667$. The standards and reference materials were packed together with the samples in each transport aluminium and plastic container. Different standards were used to choose the minimum certified uncertainties for each studied element in comparison with the standards, which contain mollusc's tissue. The standards were only used for verifying the analysis of each set of samples. 
List of elements with parameters of determination, standards and deviation between certified and determined concentrations

\begin{tabular}{|c|c|c|c|c|c|c|}
\hline $\begin{array}{l}\text { Element and } \\
\text { technique }^{*}\end{array}$ & SRM & $\begin{array}{l}\text { Determined } \\
{[\mathrm{ppm}]}\end{array}$ & $\begin{array}{l}\text { Certified } \\
\text { [ppm] }\end{array}$ & $\begin{array}{c}\text { Determined } \\
\text { uncertainty }[\%]\end{array}$ & $\begin{array}{c}\text { Certified } \\
\text { uncertainty } \\
{[\%]}\end{array}$ & $\begin{array}{c}\text { Deviation } \\
{[\%]}\end{array}$ \\
\hline $\mathrm{Na}(2)$ & 2709 & 10240 & 11600 & 3.2 & 2.6 & 11.7 \\
\hline $\mathrm{Mg}(1)$ & 2709 & 17030 & 15100 & 4.7 & 3.3 & -12.8 \\
\hline $\mathrm{Al}(1)$ & $1633 b$ & 160500 & 150500 & 4.4 & 1.8 & -6.6 \\
\hline $\mathrm{Cl}(1)$ & 1547 & 360 & 360 & 8.9 & 5.3 & 0 \\
\hline $\mathrm{K}(2)$ & 433 & 18000 & 16600 & 8.8 & 13.4 & -8.5 \\
\hline $\mathrm{Ca}(1)$ & $1633 b$ & 16100 & 15100 & 15.2 & 4 & -6.4 \\
\hline Sc (3) & 2709 & 13.8 & 12.0 & 2.9 & 30 & -14.9 \\
\hline $\mathrm{Ti}(1)$ & 2709 & 3450 & 3420 & 5.6 & 7 & -0.8 \\
\hline V (1) & 2709 & 109 & 112 & 4.2 & 4.5 & 2.7 \\
\hline $\mathrm{Cr}(3)$ & 2709 & 125 & 130 & 5.2 & 3.1 & 3.6 \\
\hline Mn (1) & 667 & 938 & 920 & 6.6 & 4.3 & -2 \\
\hline $\mathrm{Fe}(3)$ & 2709 & 35100 & 35000 & 5 & 3.1 & -0.3 \\
\hline Co (3) & 2709 & 12.8 & 13.4 & 3.4 & 5.2 & 4.8 \\
\hline $\mathrm{Ni}(3)$ & 2709 & 83 & 88 & 6.7 & 5.7 & 5.6 \\
\hline $\mathrm{Cu}(1)$ & 2709 & 106 & 106 & 4.5 & 2.8 & 0.1 \\
\hline $\mathrm{Zn}(3)$ & 433 & 17.5 & 18.9 & 6.9 & 1.3 & 7.2 \\
\hline As (2) & 2709 & 1.5 & 1.6 & 15.3 & 5.1 & 7.5 \\
\hline Se (3) & 433 & 66 & 67 & 3.1 & 11.9 & 0.9 \\
\hline $\mathrm{Br}(2)$ & 433 & 117.0 & 99.9 & 17.5 & 8.5 & -17.2 \\
\hline $\mathrm{Rb}(3)$ & 2709 & 225 & 231 & 7.3 & 0.9 & 2.7 \\
\hline $\mathrm{Sr}(3)$ & 433 & 135 & 148 & 30.9 & 30 & 8.7 \\
\hline In (1) & 2709 & 8.0 & 7.9 & 6.3 & 7.6 & -1.2 \\
\hline $\mathrm{Sb}(3)$ & 1547 & 0.3 & 0.3 & 50 & 30 & -6 \\
\hline I (1) & 433 & 7.3 & 6.4 & 4 & 4.1 & -14.4 \\
\hline Cs (3) & 433 & 260 & 268 & 10.5 & 7.1 & 3.1 \\
\hline $\mathrm{Ba}(2)$ & 2709 & 0.3 & 0.3 & 30.2 & 30 & 0 \\
\hline $\mathrm{Au}(2)$ & 433 & 10.4 & 9.8 & 3.5 & 2.9 & -6.2 \\
\hline Th (3) & 2709 & 3.5 & 3 & 3.7 & 30 & -16.9 \\
\hline $\mathrm{U}(2)$ & 2709 & 10240 & 11600 & 3.2 & 2.6 & 11.7 \\
\hline
\end{tabular}

* 1 : conventional NAA, measured 15 min after 3 min of irradiation and $\sim 3$ min of decay 2: epithermal NAA, measured 30 min after 4 days of irradiation and $\sim 3$ days of decay 3: epithermal NAA, measured 90 min after 4 days of irradiation and 22 days of decay

Deviation [\%] (Table 3) corresponded to differences between certified and calculated concentrations after neutron activation analysis. In the case of $0 \%(\mathrm{Cl}, \mathrm{Ba})$ the element was calculated by using one standard without comparative analysis between other SRMs for quality control. This was also relevant to the elements with high deviations between certified and determined concentrations in standards (As, Se, I and Au). All the determined concentrations depended on the amounts of the element in the studied material, which was taken into account during the analysis of the concentrations for such elements.

\section{Statistical procedures}

Statistical methods were applied for comparative analysis. The several studied sets of samples were not in normal distribution according to Shapiro-Wilk normality tests. The non-parametric Kruskal-Wallis test was used to check the significance of the comparison between the separate sets of samples [17]. This technique is widely used in the 
analysis of elemental accumulation in molluscs [18] in the case of inapplicable results of ANOVA tests if the transformations for obtaining normality are objectionable. Each set of samples were analysed separately by using software Statistica 11.0.

\section{Results and discussion}

\section{General characterization and revealing the groups}

Average dimensions and concentration data of the analyses are given in Table 4. The results of several elements were compared with the reference data from the indigenous CM, Mytilus edulis and MG from Saldanha Bay that was measured by Watling 40 years ago [19]. The concentrations of $\mathrm{Fe}$ and $\mathrm{Cu}$ in the soft tissue of mussels reached 120-200\% values than in the previous study for Saldanha Bay. In contrast, the current concentrations of $\mathrm{Cr}, \mathrm{Mn}, \mathrm{Co}, \mathrm{Ni}, \mathrm{Zn}$ and $\mathrm{Ag}$ reached $10-100 \%$ the values if compared to previous studies. This could be explained by changes in the hydrodynamic parameters of the bay since the previous study. excluded outliers)

\begin{tabular}{|c|c|c|c|c|c|c|}
\hline & \multicolumn{2}{|c|}{ CM } & \multicolumn{2}{c|}{ MG $^{*}$} & \multicolumn{2}{c|}{ CG $^{*}$} \\
\hline & mean & SD & mean & SD & mean & SD \\
\hline Mass [g] & 37.7 & 5.4 & 37 & 12 & 66 & 13 \\
\hline Length [mm] & 80.6 & 3.7 & 81.1 & 7.6 & 94 & 14 \\
\hline $\mathbf{N a}$ & 15360 & 1820 & 12770 & 3660 & 15460 & 3690 \\
\hline $\mathbf{M g}$ & 1990 & 210 & 1880 & 450 & 2140 & 390 \\
\hline $\mathbf{A l}$ & 86 & 29 & 50 & 20 & 67 & 22 \\
\hline $\mathbf{C l}$ & 27470 & 3970 & 26280 & 4010 & 27770 & 6220 \\
\hline $\mathbf{K}$ & 11530 & 1580 & 12600 & 1710 & 10880 & 1930 \\
\hline $\mathbf{C a}$ & 1380 & 350 & 2170 & 370 & 1300 & 1460 \\
\hline $\mathbf{S c}$ & 0.03 & 0.01 & 0.01 & 0 & 0.02 & 0.01 \\
\hline $\mathbf{V}$ & 1.0 & 0.6 & 1.2 & 0.7 & 1.06 & 0.84 \\
\hline $\mathbf{C r}$ & 0.92 & 0.88 & 0.66 & 0.14 & 0.59 & 0.41 \\
\hline $\mathbf{M n}$ & 9.1 & 3.0 & 6.3 & 1.4 & 4.9 & 2.7 \\
\hline $\mathbf{F e}$ & 110 & 50 & 190 & 30 & 110 & 50 \\
\hline $\mathbf{C o}$ & 0.21 & 0.06 & 0.21 & 0.06 & 0.21 & 0.04 \\
\hline $\mathbf{N i}$ & 0.81 & 0.35 & 0.56 & 0.18 & 0.48 & 0.33 \\
\hline $\mathbf{C u}$ & 12.7 & 5.9 & 34.5 & 7.5 & 9 & 12 \\
\hline $\mathbf{Z n}$ & 93 & 28 & 845 & 41 & 137 & 265 \\
\hline $\mathbf{A s}$ & 11.4 & 3.4 & 9.9 & 2.1 & 8.5 & 3.3 \\
\hline $\mathbf{S e}$ & 2.9 & 0.7 & 3.2 & 0.8 & 4.8 & 0.6 \\
\hline $\mathbf{B r}$ & 219 & 30 & 173 & 53 & 230 & 41 \\
\hline $\mathbf{R b}$ & 5.4 & 0.7 & 4.9 & 0.9 & 4.8 & 0.6 \\
\hline $\mathbf{S r}$ & 19.8 & 2.9 & 24.7 & 8.6 & 22.7 & 10.6 \\
\hline $\mathbf{I n}$ & 0.06 & 0.03 & 0.08 & 0.04 & 0.07 & 0.04 \\
\hline $\mathbf{S b}$ & 0.02 & 0.02 & 0.02 & 0.01 & 0.02 & 0.01 \\
\hline $\mathbf{I}$ & 4.7 & 1.5 & 3.2 & 1.5 & 3.4 & 1.2 \\
\hline $\mathbf{C s}$ & 0.03 & 0.01 & 0.02 & 0.02 & 0.03 & 0.01 \\
\hline $\mathbf{B a}$ & 1.5 & 2.9 & 0.5 & 1.2 & 1.2 & 0.8 \\
\hline $\mathbf{A u}$ & 0.003 & 0.002 & 0.002 & 0.001 & 0.002 & 0.001 \\
\hline $\mathbf{T h}$ & 0.03 & 0.02 & 0.01 & 0.01 & 0.02 & 0.01 \\
\hline $\mathbf{U}$ & 0.12 & 0.09 & 0.13 & 0.06 & 0.10 & 0.05 \\
\hline
\end{tabular}

* presented data from April and August sets were pooled. $S D$ - standard deviation 
The obtained values were also compared to the reference data for the same species of the molluscs (except for the elements $\mathrm{V}$ and $\mathrm{Cs}$ ) sampled in other coastal regions of the world [20] (Table 5). These results are shown in the form of ranges, where the extremes from reference and our studies were excluded. In general, the concentrations of the majority of elements in the molluscs for this study have lower values if compared to the reference data [20]. However, elements such as $\mathrm{Mn}$ and As (Table 1) were accumulated by indigenous mussels (CM), Se by alien mussels (MG) and $\mathrm{Cu}$ by alien oysters (CG) in the higher concentrations. This could be a result of the unique elemental composition of the water around the suspended molluscs in the studied area of inner Saldanha Bay.

The minimum and maximum interquartile ranges of elemental concentrations in the three different species of molluscs (CM, MG and CG) in Saldanha Bay correspond at the same orders of values with other studies, which will be used as referenced data (Table 5). The slightly lower concentrations for certain elements, when compared to the reference data, reflect the absence of a constant or dramatic influence of anthropogenic influences during the studied period.

Ranges of concentration [ppm] of several elements in different molluscs (soft tissue, dry weight) according to reference data and interquartile ranges for our data

\begin{tabular}{|c|c|c|c|c|c|c|}
\hline & \multicolumn{3}{|c|}{ Reference data [20] } & \multicolumn{3}{|c|}{ This study } \\
\hline & $\mathrm{CM}$ & MG & CG & $\mathrm{CM}$ & $\mathrm{MG}^{*}$ & $\mathrm{CG}^{*}$ \\
\hline $\mathbf{V}$ & \multicolumn{3}{|c|}{$0.4-8.5^{* *}$} & $0.6-1.6$ & $0.66-2.5$ & $0.62-1.60$ \\
\hline $\mathrm{Cr}$ & $0.3-1.1$ & $0.3-1.1$ & $0.3-1.1$ & $0.20-1.25$ & $0.51-0.77$ & $0.29-0.75$ \\
\hline Mn & $2.6-6.8$ & $2.6-6.8$ & $2.6-6.8$ & $6.34-11.6$ & $3.7-6.0$ & $3.4-8.4$ \\
\hline $\mathbf{F e}$ & $94-260$ & $94-260$ & $94-260$ & $77-130$ & $98-129$ & $152-226$ \\
\hline Co & $0.13-0.33$ & $0.13-0.33$ & $0.13-0.33$ & $0.17-0.26$ & $0.17-0.25$ & $0.17-0.22$ \\
\hline $\mathrm{Ni}$ & $0.3-1.1$ & $0.3-1.1$ & $0.3-1.1$ & $0.58-1.18$ & $0.30-0.79$ & $0.3-0.8$ \\
\hline $\mathbf{C u}$ & $13-23$ & $13-23$ & $13-23$ & $9-16$ & $2-15$ & $26-41$ \\
\hline $\mathbf{Z n}$ & $90-235$ & $90-235$ & $90-235$ & $77-102$ & 101-177 & $640-990$ \\
\hline As & $4.0-10.6$ & $4.0-10.6$ & $4.0-10.6$ & $8.5-14.6$ & $7.3-9.4$ & $7.1-12.4$ \\
\hline Se & $2.5-5.2$ & $2.5-5.2$ & $2.5-5.2$ & $2.4-3.6$ & $4.4-5.1$ & $2.9-3.6$ \\
\hline Cs & \multicolumn{3}{|c|}{$0.001-0.130^{*}$} & $0.026-0.041$ & $0.021-0.031$ & $0.016-0.027$ \\
\hline
\end{tabular}

* presented data from April and August sets were pooled

${ }^{* * *}$ concentrations were given for several other species of bivalves (Mytilus edulis etc.)

It is interesting to note that elements such as $\mathrm{V}$, Co and Se were accumulated by mussels and oysters (CM and CG) in almost equal amounts (Table 5). Co, for example, also accumulated similar concentrations in all three species of molluscs and these concentrations are also comparable to the reference data (Table 5). These results confirm the claim that these elements accumulated due to natural fluxes of water masses and probably could be associated with the suspended terrigenous matter.

The Kruskal-Wallis test illustrated significant differences between species, locations and dates (Table 6). $\mathrm{P}$ values for presented elements are given in brackets. It allows for the comparison of four sets of samples. The interspecies differences between CM and GM were investigated at site 1 in April 2016. Temporal comparisons were made between the data sets for April and August in terms of MG at site 1. Oysters CG were spatially (site 2 and 3) compared during August.

In similar conditions (dates and location) the indigenous mussels (CM) accumulated $\mathrm{Mn}$ and As in the higher amounts than alien mussels (MG) (Fig. 2). On the contrary, alien mussels (MG) accumulated $\mathrm{Zn}$ and $\mathrm{Se}$ in the higher concentrations than indigenous mussels 
(CM). Alien mussels (MG), if compared to the alien oysters (CG) during August, accumulated the higher concentrations of S, Se and Br (Fig. 3). Whereas the alien oysters (CG) accumulated the higher concentration of $\mathrm{Fe}, \mathrm{Cu}, \mathrm{Zn}$ and $\mathrm{As}$ than the alien mussels (MG) during this time. Other elements were not significantly different amongst the species. The data reflected the specificity of accumulation of elements by the mussels. It is probably caused by the specificity of molluscs, absorption preferences and the environmental conditions that guide accessibility to chemical compounds. The general group of low volatile elements of terrigenous origin (clay minerals, carbonates, detrital particles in marine sediments) such as $\mathrm{Co}, \mathrm{Sc}, \mathrm{Cr}, \mathrm{Ni}, \mathrm{Sb}, \mathrm{Cs}$ and others [21, 22] revealed relatively equal ranges of concentrations in all three species (CM, MG and CG).

Table 6

Results of the Kruskal-Wallis test based on 4 different sets of samples

\begin{tabular}{|c|c|c|c|}
\hline Species & Location & Month & Elements after Kruskal-Wallis test with $\boldsymbol{p}<\mathbf{0 . 0 5}$ \\
\hline CM-MG & site1 & April & $\mathrm{Mn}(0.002), \mathrm{Zn}(0.03), \mathrm{As}(0.02), \mathrm{Se}(0.002)$ \\
\hline MG-MG & site1 & April-August & $\mathrm{S}(0.01), \mathrm{V}(0.004), \mathrm{Co}(0.005), \mathrm{Br}(0.02), \mathrm{Se}(0.01)$ \\
\hline CG-CG & $\begin{array}{c}\text { site } 2^{*}- \\
\text { site } 3\end{array}$ & August & $\begin{array}{r}\mathrm{V}(0.01), \mathrm{Fe}(0.01), \mathrm{Co}(0.02), \\
\mathrm{Cu}(0.01), \mathrm{As}(0.0004), \mathrm{Se}(0.002)\end{array}$ \\
\hline
\end{tabular}

* Site 2 corresponded relatively well to site 1 due to uniformity of the hydrological structure of Small Bay

a)

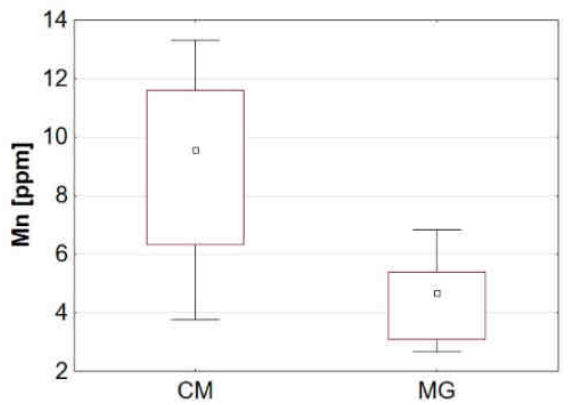

c)

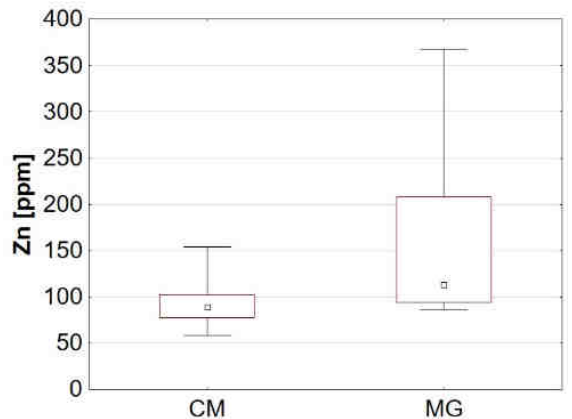

b)

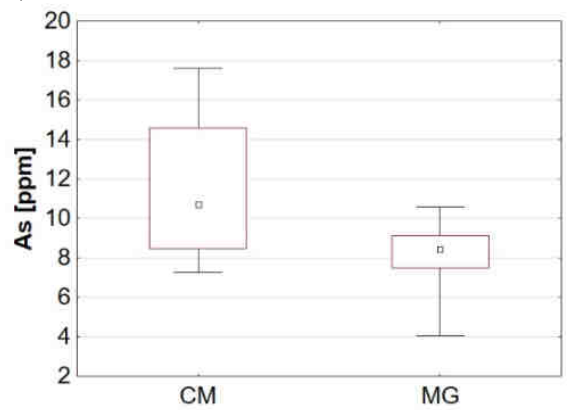

d)

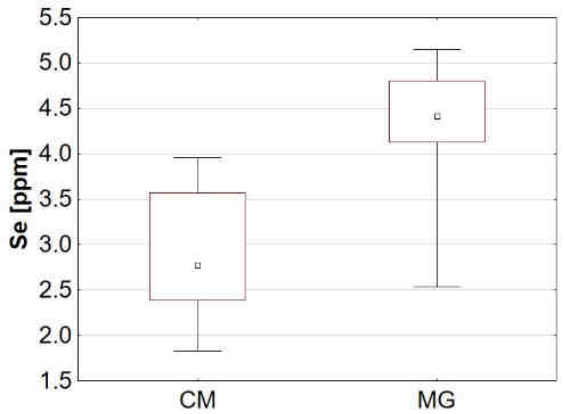

Fig. 2. Concentrations of: a) Mn, b) As, c) Zn and d) Se in CM and MG at site 1 (The points represent the means, the boxes represent the interquartile ranges $25-75 \%$ and the whiskers - the minimum and maximum values) 
a)

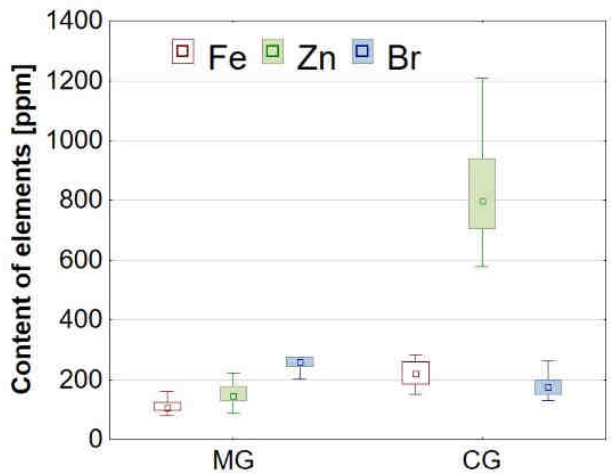

b)

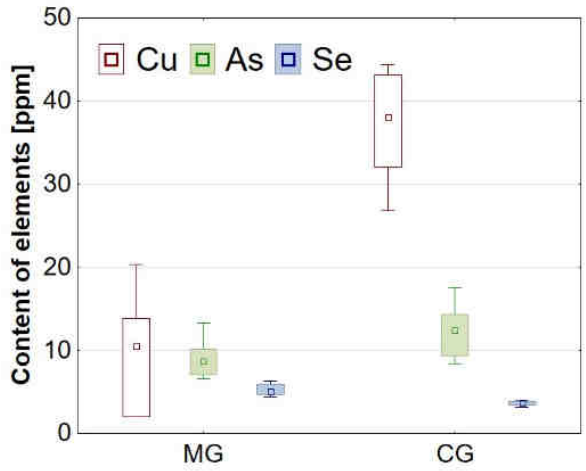

Fig. 3. Concentrations of: a) $\mathrm{Fe}, \mathrm{Zn}, \mathrm{Br}$ and b) $\mathrm{Cu}, \mathrm{As}$, Se for $\mathrm{MG}$ and $\mathrm{CG}$ (The points represent the means, the boxes represent the interquartile ranges $25-75 \%$ and the whiskers - the minimum and maximum values)

a)

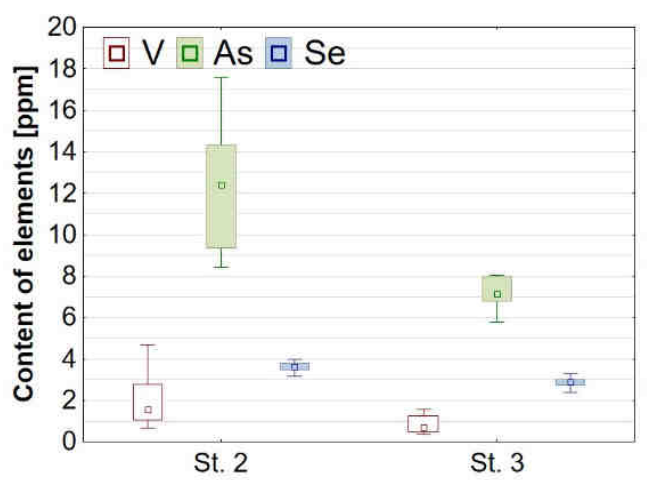

b)

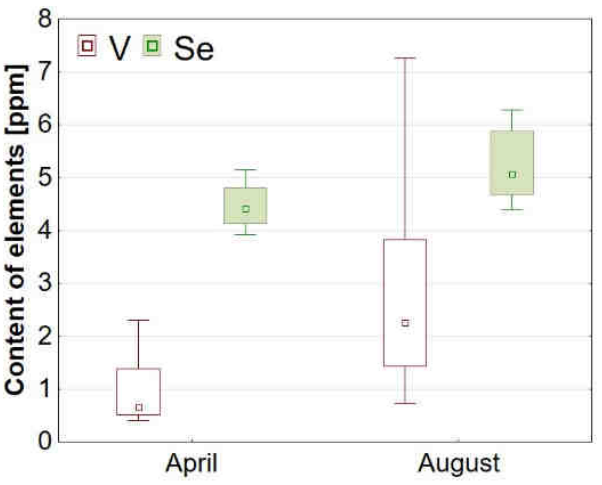

Fig. 4. Concentrations of: a) V and Se in mussels (MG) for April and August; b) V, As and Se in oysters (CG) at site 2 and site 3 (The points represent the means, the boxes represent the interquartile ranges $25-75 \%$ and the whiskers - the minimum and maximum values)

Elements such as $\mathrm{S}, \mathrm{V}, \mathrm{Se}$ and $\mathrm{Br}$ accumulated in significantly higher concentrations in alien mussels (MG) that were collected during August rather than in April in Small Bay (Fig. 4). Mussels, which were collected in April, demonstrated lower concentrations in all elemental concentrations. This is similar to what was found by Bezuidenhout et al. [14]. In this paper, it was suggested that the mussels accumulated elements during winter in preparation for the spawning season in summer. This may also be due to seasonal differences (based on two month April and August) in the elemental composition of the bay's water. South-easterly to southerly winds result in upwelling in the bay that adverts cold waters with lower salinity and oxygen deficiency [17]. The seasonal changes may also be due to the availability of food, which coincides, with the growth of phytoplankton. The high production of phytoplankton is usually linked to low metal concentrations since the ready availability of food would lead to a high metabolic and excretion rate [23]. 
The higher than normal biogenic threshold needs additional $\mathrm{S}$ and Se during this lifecycle. Figure $4 \mathrm{~b}$ demonstrates that $\mathrm{V}, \mathrm{Fe}, \mathrm{Cu}, \mathrm{As}$, Se and some other elements significantly accumulated in oysters, which were collected from the Small Bay (site 2) in comparison to the oysters from Big Bay (site 3).

The following three types of elemental characteristics were found among the species (compare Figures 2-4 and Tables 4-6). These were based on mean values and interquartile ranges of the elemental concentrations excluding outliers:

- Indigenous mussels (CM) accumulated $\mathrm{Mn}$ and As in higher amounts than alien mussels (MG).

- $\quad$ Alien mussels accumulated $\mathrm{Zn}$ and Se in the higher amounts than indigenous mussels. Alien mussels also accumulated $\mathrm{S}, \mathrm{Se}$ and $\mathrm{Br}$ in the higher concentrations than alien oysters (CG).

- Oysters accumulated $\mathrm{Fe}, \mathrm{Cu}, \mathrm{Zn}$ and $\mathrm{As}$ in the significantly higher concentrations than alien mussels. Lower concentrations of $\mathrm{Br}$ were found in oysters in comparison to mussels

The wide range in elemental concentrations could also reflect the disparity of the biological accumulation in the studied area. In general, the CM demonstrated higher fluctuations in Mn, As and other elements if compared to MG. It may reflect the flexibility of the indigenous species with seasonal fluctuations of elemental concentrations in the water. According to the study [24], the high trace element levels were found in the seston and this was attributed to trace element enrichment in bivalve molluscs. The enrichment essentially takes place in a twofold mechanism: the first being the prior pre-concentration of trace elements into the particulate material in the water column (complexing, inclusion, precipitation); the second being the ingestion of this particulate material by the organism.

The $\mathrm{Fe}, \mathrm{Cu}$ and $\mathrm{Zn}$ are usually accumulated in the higher amounts by oysters than by mussels [25]. MG accumulated the well-known marine elements such as $\mathrm{Se}$ and $\mathrm{Br}$ in higher amounts but with a wider spread in the range of values, compared with CG and CM. The differences between the two mussel species could be associated with interspecific accumulation properties. The higher amounts of these elements in MG are probably due to an unstable environment with the alien species not adapted to such local changes. In contrast, the indigenous species have a higher tolerance to quick hydrochemical changes of the water and the subsequent release of excess elements into the water.

\section{Traits of elemental accumulation in all studied molluscs}

The $\mathrm{Cu}$ was accumulated in the wider range of concentrations in alien mussels (MG) if compared to Fe and $\mathrm{Zn}$. It is well known that small oysters and other bivalve molluscs take up $\mathrm{Cu}$ at a greater rate than larger conspecifics [25]. Uptake of $\mathrm{Cu}$ by mussels is more erratic and seems to be influenced by available concentrations of $\mathrm{Zn}, \mathrm{Cd}$, and $\mathrm{Pb}$ salts [26]. This is supported by the elemental concentration data of MG and CM in this study. According to [19] alien mussels (MG) demonstrated a decrease in $\mathrm{Cu}$ concentration with increasing body weight. In industrialized areas, $\mathrm{Cu}$ reached values that ranged from 8.3-49.0 ppm dry weight in MG, with $148 \mathrm{ppm}$ being the maximal when background concentrations are 7.6-9.7 ppm [20].

In many cases, the high $\mathrm{Cu}$ concentrations were associated with the proximity of anthropogenic sources of $\mathrm{Cu}$, and secondarily to the biotic and abiotic variables that influence $\mathrm{Cu}$ uptake and retention. Maanan [27], for example, showed that concentrations of $\mathrm{Cu}$ in $\mathrm{CG}$ reached $42 \mathrm{ppm}$ in the sites that were close to sources of fertilizers pollution. 
It was demonstrated that $\mathrm{MG}$ accumulated $\mathrm{Cu}$ concentrations of $10-90 \mathrm{ppm}$, with a maximal value of $150 \mathrm{ppm}$, depending on the dates and proximity of the samples sites to the sources of pollution. In this study, the similar concentrations were obtained for oysters but only reached $10 \mathrm{ppm}$ for $\mathrm{MG}$, which is comparable to the lower levels of the reference data. It should be emphasized that in [27] sampled molluscs that were on average $5 \mathrm{~cm}$ in body length, which is considerably smaller than the molluscs in this study, which ranged from 7 to $11 \mathrm{~cm}$ for mussels and oysters. Fluctuations in the $\mathrm{Zn}$ content in the tissues of Perna viridis [28] were related to mussel size and were so large (from minimal to maximal values) to conceal low chronic or short-term pollution. Variations in the $\mathrm{Zn}$ content of clam tissues, for example, were associated with seasonal changes in tissue weights [29]. The range of Co in MG is 0.3-2.1 ppm. It is important to note that the third quartile in the reference data was two times higher in the mussel concentrations (MG and $\mathrm{CM}$ ) and four times higher in the CG.

The complex environment of the Saldanha Bay is created by the high level of nutrients from the Antarctic waters that feed the west coast of South Africa and aeolian industrial fallout of anthropogenic activities around the bay. The concentrations of trace metals in tissue depend on various environmental parameters such as salinity, temperature, the organic content of water, geochemical composition of suspended matter and the content of the bottom sediments, which sometimes relate to anthropogenic impact. It is well documented that salinity of the water is an important factor that influences the concentration of selected metals in the soft tissue of Mytilus edulis [30]. In this study, the environmental conditions for different sampled mussels were the same. The study, therefore, obtained results that indicated concentration patterns due to interspecies differences in selective accumulation of elements.

\section{Accumulation differences between the mussels}

In comparison with the indigenous mussels (CM), the alien mussels (MG) exhibited heightened growth rates, fecundity and tolerance to desiccation [31]. Relative to CM, MG also grows faster in absolute terms under optimal conditions [32]. Its annual reproductive output, expressed as a percentage of its body mass, exceeds $120 \%$ as it reproduces more than once each year [33]. Its total annual output is between 20 and $200 \%$, which is greater than any of the indigenous species in Saldanha Bay. This means that the elements, which are incorporated in particles and food, accumulated faster to critical values and the process of self-cleaning starts earlier in MG. The results indicated that this trait relates to elements such as $\mathrm{Mn}$ and As, but the opposite is for Se and Br.

MG is only inferior in terms of tolerance to siltation if compared to the local species. MG is severely affected by siltation, whereas CM adapts relatively well [34]. It is consequently only in sandy areas that $\mathrm{CM}$ remains dominant. This could be because the MG accumulates the majority of elements in the narrower range if compared to CM and CG. MG beds in natural conditions usually consist of multiple layers and support a higher biomass per $\mathrm{m} 2$ than the single-layered beds of indigenous mussels. The increased vertical range of MG beds usually accompanied in the high density of associated infauna [32, 35]. All these characteristics emphasise that the elements can be accumulated differently by alien mussels in smaller periods. It is important to note that $\mathrm{Cr}, \mathrm{Mn}, \mathrm{Ni}$ and $\mathrm{Cs}$ accumulated in the smaller concentrations in alien species MG and CG in comparison to the indigenous CM. This probably reflects the features of the process of adaptation of alien species to 
foreign semi-closed coastal environments with suspended clay sediments which contain such elements.

\section{Conclusion}

In general, the Mytilus galloprovincialis demonstrated a significantly higher accumulation ability to $\mathrm{S}$, Se and $\mathrm{Br}$ than Crassostrea gigas. While the Crassostrea gigas showed a relatively higher accumulation ability to $\mathrm{Fe}, \mathrm{Cu}$ and $\mathrm{Zn}$. Interspecies differences were also found between mussels, Choromytilus meridionalis has a higher ability to accumulate $\mathrm{Mn}$ and As and the Mytilus galloprovincialis to $\mathrm{Zn}$ and Se. It was concluded that all the bivalve molluscs present themselves as effective biomonitors and indicators of anthropogenic pollution, but that accumulation ability to certain elements can be amplified by a dedicated selection of species. More research is required for the investigation of more varying coastal environments and the testing of larger sample sizes.

\section{Acknowledgements}

This study was supported by the JINR-NRF of South Africa grants in 2016-2017 (Order \# 430 of 28.06 .2016 , p.2, and Order \# 658 of 28.09 .2017 , p. 2.)

\section{References}

[1] Azizi G, Layachi M, Akodad M, Yáñez-Ruiz DR, Martín-García AI, Baghour M, et al. Seasonal variations of heavy metals content in mussels (Mytilus galloprovincialis) from Cala Iris offshore (Northern Morocco). Marine Pollut Bull. 2018;137:688-94. DOI: 10.1016/j.marpolbul.2018.06.052.

[2] Krishnakumar PK, Qurban MA, Sasikumar G. Biomonitoring of trace metals in the coastal waters using bivalve molluscs. In: Saleh HEM, El-Adham E, editors. Trace Elements - Human Health and Environment. InTech; 2018. DOI: 10.5772/intechopen.76938.

[3] Dallarés S, Carrasco N, Álvarez-Muñoz D, Rambla-Alegre M, Solé M. Multibiomarker biomonitoring approach using three bivalve species in the Ebro Delta (Catalonia, Spain). Environ Sci Pollut Res. 2018;25(36):36745-58. DOI: 10.1007/s11356-018-3614-6.

[4] Goldberg ED. The mussel watch - A first step in global marine monitoring. Marine Pollut Bull. 1975;6(7):111. DOI: 10.1016/0025-326x(75)90271-4.

[5] Sparks C, Odendaal J, Snyman R. An analysis of historical Mussel Watch Programme data from the west coast of the Cape Peninsula, Cape Town. Marine Pollut Bull. 2014;87(1-2):374-80. DOI: 10.1016/j.marpolbul.2014.07.047.

[6] Buzzi NS, Marcovecchio JE. Heavy metal concentrations in sediments and in mussels from Argentinean coastal environments, South America. Environ Earth Sci. 2018;77(8):321. DOI: 10.1007/s12665-018-7496-1.

[7] Clark BM, Massie V, Hutchings K, Brown E, Biccard A, Laird M, et al. The State of Saldanha Bay and Langebaan Lagoon 2017. Technical Report. Report No. AEC 1741/1 prepared by Anchor Environmental Consultants (Pty) Ltd for the Saldanha Bay Water Quality Forum Trust. Available from: http://www.anchorenvironmental.co.za/node/339.

[8] Degger N. The application of passive artificial devices for monitoring of metallic and organic pollutants along the South African coastline. PhD Thesis. Johannesburg: University of Johannesburg; 2010. Available from: ujcontent.uj.ac.za.

[9] Stankovic S, Jovic M. Health risks of heavy metals in the mediterranean mussels as seafood. Environ Chem Lett. 2011;10(2):119-30. DOI: 10.1007/s10311-011-0343-1.

[10] Robinson TB, Peters K, Brooker B. Coastal invasions: the South African context. In: Biological Invasions in South Africa. Cham: Springer; 2020: 229-47. DOI: 10.1007/978-3-030-32394-3_9.

[11] Zardi GI, McQuaid CD, Jacinto R, Lourenço CR, Serrão EA, Nicastro KR. Re-assessing the origins of the invasive mussel Mytilus galloprovincialis in southern Africa. Marine Freshwater Res. 2018;69(4):607-13. DOI: $10.1071 / \mathrm{mf} 17132$.

[12] Firth DC. Temporal and inter-species variations in the proximate and contaminant compositions of farmed mussels, Choromytilus meridionalis and Mytilus galloprovincialis, from Saldanha Bay, South Africa. PhD 
Thesis. Stellenbosch: Stellenbosch University; 2018. Available from: http://scholar.sun.ac.za/handle/10019.1/103907.

[13] Pavlov DF, Bezuidenhout J, Frontasyeva MV, Goryainova ZI. Differences in trace element content between non-indigenous farmed and invasive bivalve mollusks of the South African Coast. Am J Analyt Chem. 2015;6(11):886. DOI: 10.4236/ajac.2015.611084.

[14] Bezuidenhout J, Dames N, Botha A, Frontasyeva MV, Goryainova ZI, Pavlov D. Trace elements in mediterranean mussels mytilus galloprovincialis from the South African west coast. Ecoll Chem Eng S. 2015;22(4):489-98. DOI: 10.1515/eces-2015-0028.

[15] Pavlov SS, Dmitriev AY, Frontasyeva MV. Automation system for neutron activation analysis at the reactor IBR-2, Frank Laboratory of neutron physics, Joint Institute for Nuclear Research, Dubna, Russia. J Radioanal Nuclear Chem. 2016;309(1):27-38. DOI: 10.1007/s10967-016-4864-8.

[16] Frontasyeva MV. Neutron activation analysis in the life sciences. Phys Particles Nuclei. 2011;42(2):332-78. DOI: $10.1134 / \mathrm{s} 1063779611020043$.

[17] Hecke TV. Power study of Anova versus Kruskal-Wallis test. J Statistics Manage Systems. 2012;15(2-3):241-7. DOI: 10.1080/09720510.2012.10701623.

[18] Donrovich SW, Douda K, Plechingerová V, Rylková K, Horký P, Slavík O. Invasive Chinese pond mussel Sinanodonta woodiana threatens native mussel reproduction by inducing cross-resistance of host fish. Aquatic Conservation: Marine Freshwater Ecosystems. 2017;27(6):1325-33. DOI: 10.1002/aqc.2759.

[19] Watling HR, Watling RJ. Trace metals in Choromytilus meridionalis. Marine Pollut Bull. 1976;7(5):91-4. DOI: $10.1016 / 0025-326 x(76) 90149-1$.

[20] Eisler R. Molluscs. Compendium of Trace Metals and Marine Biota. 1st ed. Amsterdam: Elsevier; 2010: 143-397. DOI: 10.1016/b978-0-444-53439-2.00006-0.

[21] Dekov VM, Darakchieva VY, Billström K, Garbe-Schönberg CD, Kamenov GD, Gallinari M, et al. Element enrichment and provenance of the detrital component in Holocene sediments from the western Black Sea. Oceanologia. 2020;62(2):139-63. DOI: 10.1016/j.oceano.2019.10.001.

[22] Smrzka D, Zwicker J, Bach W, Feng D, Himmler T, Chen D, et al. The behavior of trace elements in seawater, sedimentary pore water, and their incorporation into carbonate minerals: A review. Facies. 2019;65(4):41. DOI: 10.1007/s10347-019-0581-4.

[23] Cabrita MT, Brito P, Caçador I, Duarte B. Impacts of phytoplankton blooms on trace metal recycling and bioavailability during dredging events in the Sado estuary (Portugal). Marine Environ Res. 2020;153:104837. DOI: 10.1016/j.marenvres.2019.104837.

[24] Wang F, Zhou Y, Wang P, Xu S, Liu P. Potential role of scallops Argopecten irradians in deposition of particulate nutrient and trace elements in a eutrophic estuary, northern China. Aquaculture Environ Interactions. 2018;10:135-47. DOI: 10.3354/aei00258.

[25] Sami M, K Ibrahim N, A Mohammad D. Impact of the size of commercial bivalves on bioaccumulation and depuration of heavy metals. Egypt J Aquatic Biol Fisheries. 2020;24(7-SI):553-73. DOI: 10.21608/ejabf.2020.122312.

[26] Azizi G, Akodad M, Baghour M, Layachi M, Moumen A. The use of Mytilus spp. mussels as bioindicators of heavy metal pollution in the coastal environment. A review. J Mater Environ Sci. 2018;9(4):1170-81. Available from: https://www.jmaterenvironsci.com/Journal/vol9-4.html.

[27] Maanan M. Heavy metal concentrations in marine molluscs from the Moroccan coastal region. Environ Pollut. 2008;153(1):176-83. DOI: 10.1016/j.envpol.2007.07.024.

[28] Afandi MF, Widowati I, Ambariyanto A. Zinc content in water, sediment, and soft tissue of green mussel Perna viridis in Demak, Indonesia. Aquaculture, Aquarium, Conservation Legislation. 2019;1 AACL Bioflux 2(1):201-8. Available from: http://www.bioflux.com.ro/aacl.

[29] Tenjing SY, Narasimhaiah N, Hemachandra, Ciabotti C. Seasonal concentrations of heavy metals and environmental parameters with reference to the Indian largest wedge clam, Donax scortum (Linnaeus, 1758). Indian J Geo Marine Sci. 2020:49(10):1627-1635. Available from: http://nopr.niscair.res.in/handle/123456789/55638.

[30] Przytarska JE, Sokołowski A, Wołowicz M, Hummel H, Jansen J. Comparison of trace metal bioavailabilities in European coastal waters using mussels from Mytilus edulis complex as biomonitors. Environ Monitoring Assess. 2010;166(1-4):461-76. DOI: 10.1007/s10661-009-1015-5.

[31] Emanuel MP, Pillay D, van der Merwe M, Branch GM. Interactive effects of pH and temperature on native and alien mussels from the west coast of South Africa. Afr J Marine Sci. 2020;42(1):1-2. DOI: 10.2989/1814232x.2019.1699162.

[32] Branch GM, Steffani CN. Can we predict the effects of alien species? A case-history of the invasion of South Africa by Mytilus galloprovincialis (Lamarck). J Experimental Marine Biol Ecol. 2004;300(1-2):189-215. DOI: 10.1016/j.jembe.2003.12.007. 
[33] van Erkom Schurink C, Griffiths CL. A comparison of reproductive cycles and reproductive output in four southern African mussel species. Marine Ecol Progress Ser. 1991:123-34. DOI: 10.3354/meps076123.

[34] Skein L, Alexander M, Robinson T. Contrasting invasion patterns in intertidal and subtidal mussel communities. Afr Zoology. 2018;53(1):47-52. DOI: 10.1080/15627020.2018.1448720.

[35] Lindberg C, Griffiths CL, Anderson RJ. Colonisation of South African kelp-bed canopies by the alien mussel Mytilus galloprovincialis: extent and implications of a novel bioinvasion. Afr J Marine Sci. 2020;42(2):167-76. DOI: 10.2989/1814232x.2020.1754908. 